\title{
Tartrate resistant acid phosphatase positive splenic lymphoma: a relatively benign condition occurring in a time-space cluster?
}

\author{
P Kettle, T C M Morris, G M Markey, H D Alexander, R C Curry, D Hayes, \\ C H S Cameron, P G Toner
}

\begin{abstract}
Conventional light and electron microscopic studies, together with cytochemical and immunocytochemical staining procedures, were carried out to ascertain whether the lymphomata of four elderly female patients living within 10 kilometres of each other, who presented within a short space of time with massive splenomegaly and varying cytopenia, belonged to any particular subgroup of lymphoma. In each case the lymphoma had a diffuse pattern and mature $B$ cell phenotype. The malignant cells were of uniform cell type, slightly larger than admixed polymorphonuclear leucocytes, and showed minimal nuclear irregularity and positivity for tartrate resistant acid phosphatase (TRAP) staining. Their clinical and morphological features were compared with those of other lymphoproliferative disorders, but while sharing some features in common with each condition, this small group of patients seemed to have a unique combination of findings. The cytopenias of all four responded well after removal of the spleen and their disease has not been aggressive.

It is concluded that these patients have a distinct subgroup of lymphoma, which it is important to recognise so that inappropriate use of aggressive cytotoxic drugs can be avoided.
\end{abstract}

Department of
Haematology,
Belfast City Hospital,
Belfast BT9 7AD,
Northern Ireland
P Kettle
T C M Morris
G M Markey
H D Alexander
Department of
Histopathology
D Hayes
Department of
Surgery
R C Curry
Department of
Pathology, Queens
University, Belfast
C H S Cameron
P G Toner
Correspondence to:
Dr P Kettle
Accepted for publication
30 May 1990

New methods of identifying different lymphocyte populations have shown that clinical variability among lymphoreticular disorders can be due to many different diseases presenting in a similar manner. It is important to identify clearly defined prognostic subgroups from among these disorders, especially in the elderly, to avoid the inappropriate use of aggressive cytotoxic regimens. We present the findings in a group of patients with a lymphoma all of whom lived within $10 \mathrm{~km}$ of each other. They all presented within a short space of time with massive splenomegaly and the presence of atypical lymphoid cells, resembling prolymphocytes, in the peripheral blood and bone marrow. These cells were tartrate resistant acid phosphatase (TRAP) positive. The findings in these patients were compared with typical findings in other forms of chronic B cell leukaemia/lymphoma.

\section{Methods}

Four patients presented at a peripheral hospital between March 1987 and August 1988 and were referred to the Haematology Department of the Belfast City Hospital for further investigation. They all lived in the East Antrim area, within $10 \mathrm{~km}$ of each other. They all had abdominal discomfort due to splenomegaly, together with symptoms of lethargy, night sweats, and weight loss. Lymphadenopathy was not detected clinically nor on computed tomographic scanning of chest and abdomen. They all had massive splenomegaly, with various degrees of peripheral blood cytopenia and atypical lymphoid cells in the peripheral and bone marrow. None of the patients had an $M$ band in their serum or urine. The clinical and haematological features are summarised in table 1.

All four patients were given pneumococcal vaccine; their spleens were removed which they tolerated very well. The symptoms of lethargy and sweating disappeared, and three of the four patients were alive and well $20-37$ months after surgery. Cases 3 and 4 had no abnormal clinical findings; case 1 was treated with chlorambucil when pancytopenia recurred 18 months later and has responded well. Case 2 was well for some months after surgery but developed bronchogenic carcinoma and died eight months later.

Cell morphology was studied by light microscopy in peripheral blood and bone marrow films stained with Wright's stain. The spleens were examined grossly, touch preparations made, and blocks fixed in buffered formalin within 15 minutes of excision. Demonstration of acid phosphatase and tartrate resistant acid phosphatase activity on peripheral blood and bone marrow smears and on cytocentrifuged cells from bone marrow and peripheral blood, and on splenic imprints was performed according to the recommendations of the International Committee for Standardization in Haematology. ${ }^{1}$

Table 1 Clinical characteristics of patients studied

\begin{tabular}{|c|c|c|c|c|}
\hline $\begin{array}{l}\text { Case No } \\
\text { Sex } \\
\text { Age (years) } \\
\text { Splenomegaly } \\
\text { Lymphadenopathy } \\
\text { Haemoglobin } / \mathrm{dl} \\
\text { Platelets } \times 10^{9} / 1 \\
\text { White cell count }\end{array}$ & $\begin{array}{l}1 \\
F \\
57 \\
+++ \\
0 \\
11 \cdot 4 \\
83\end{array}$ & $\begin{array}{c}2 \\
\mathbf{F} \\
77 \\
+++ \\
0 \\
8 \cdot 5 \\
159\end{array}$ & $\begin{array}{c}3 \\
F \\
63 \\
+++ \\
0 \\
5 \cdot 4 \\
144\end{array}$ & $\begin{array}{c}\mathbf{4} \\
\mathbf{F} \\
\mathbf{7 7} \\
+++ \\
0 \\
12 \cdot 2 \\
112\end{array}$ \\
\hline $\begin{array}{l}\text { White cell count } \\
\times 10^{9} / 1 \\
\text { Splenectomy } \\
\text { Spleen size }(\mathrm{kg})\end{array}$ & $\begin{array}{l}2 \cdot 7 \\
\underset{2 \cdot 1}{\operatorname{March}} 87\end{array}$ & $\begin{array}{c}10 \cdot 2 \\
\text { June } 87 \\
2 \cdot 36\end{array}$ & $\begin{array}{c}2.5 \\
\text { June } 88 \\
3.66\end{array}$ & $\begin{array}{c}6 \cdot 3 \\
\text { August } 88 \\
1 \cdot 1\end{array}$ \\
\hline
\end{tabular}


Figure 1 (A)

Romanovsky stained cytospin of bone marrow aspirate showing typical lymphoid cells.

(B) Cytospin of bone marrow aspirate showing TRAP positive cells (case 2).

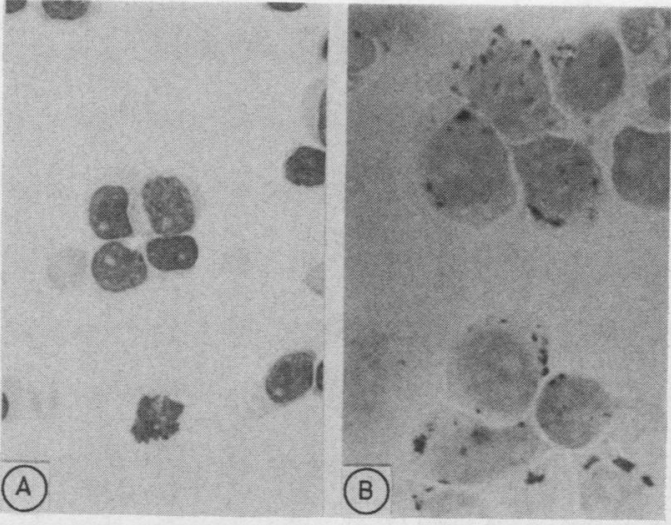

The alkaline phosphatase-antialkaline phosphatase (APAAP) technique, ${ }^{2}$ with monoclonal antibodies to $\mathrm{CD} 19,22,5,2,3,4,8$ antigens and polyclonal anti-immunoglobulins to $\mu, \kappa$, and $\lambda$ was used to study lymphocyte antigens on cytospin or touch preparations. Formation of rosettes with mouse erythrocytes was also studied on peripheral blood and bone marrow samples. Electron microscopic studies were carried out on a freshly prepared buffy coat of either peripheral blood samples or samples of splenic tissue from all patients using standard techniques.

\section{Results}

CYTOLOGICAL FEATURES OF PERIPHERAL BLOOD AND BONE MARROW

Abnormal lymphoid cells were present in the peripheral blood of all four patients and comprised $20-70 \%$ of the lymphoid population. The bone marrow aspirated easily in all patients and showed infiltration. The characteristic lymphoid cell in the peripheral blood and bone marrow smears was similar in size to

Table 2 Immunohistochemical characteristics of peripheral blood lymphocytes

\begin{tabular}{llllllll}
\hline \multirow{2}{*}{ Case No } & $\begin{array}{l}\text { Lymphocytes } \\
\times 10^{9} / l\end{array}$ & $\begin{array}{l}\text { TRAP } \\
\text { staining }\end{array}$ & $\begin{array}{l}\text { Absolute } \\
\text { T cells } \\
\times 10^{9} / l\end{array}$ & $\begin{array}{l}\text { Absolute } \\
\text { B cells } \\
\times 10^{9} / l\end{array}$ & $\begin{array}{l}\text { Mouse } \\
\text { Rosettes }\end{array}$ & $\kappa \%$ & $\lambda \%$ \\
\hline 1 & 1.5 & $20 \%$ & 0.8 & 0.6 & Nil & $45 \%$ & $2 \%$ \\
2 & $7 \cdot 1$ & $58 \%$ & 3.9 & 3.2 & $25 \%$ & $2 \%$ & $66 \%$ \\
3 & 2.5 & $17 \%$ & 1.9 & 0.6 & $0.5 \%$ & $29 \%$ & $11 \%$ \\
4 & 3.8 & $19 \%$ & 0.9 & 2.6 & ND & $71 \%$ & $0 \%$ \\
\hline
\end{tabular}

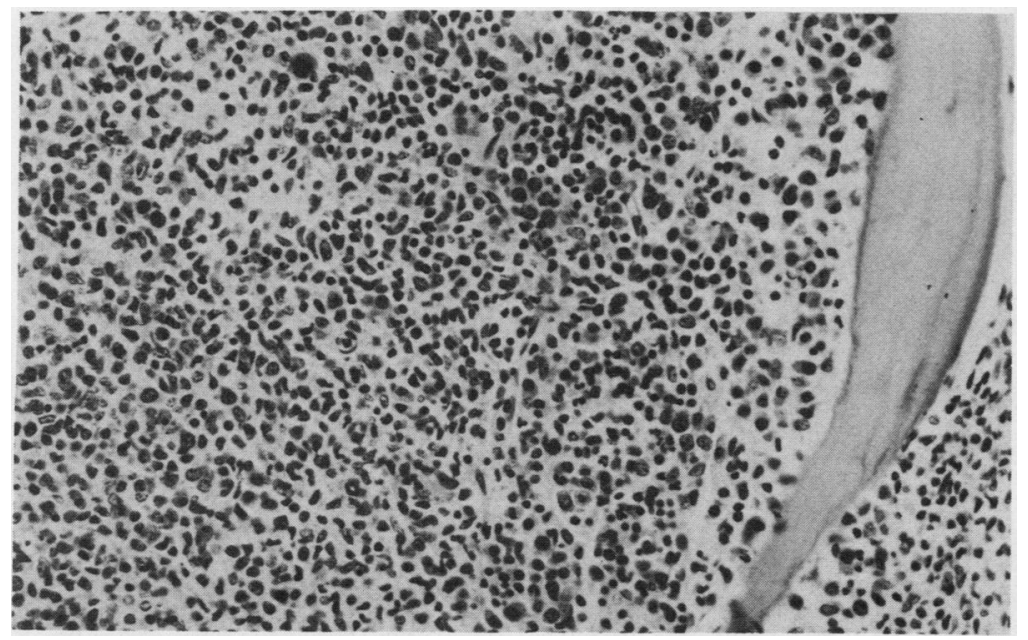

Figure 2 Trephine biopsy specimen of bone marrow (case 1) (haematoxylin and eosin). the prolymphocytes of $\mathrm{B}$ cell prolymphocytic leukaemia (fig 1A). Many exhibited a single prominent nucleolus. Cytoplasm was moderately abundant and mildly basophilic. A small number of cells had a few irregularly distributed small surface projections which were not consistent with a diagnosis of either hairy cell leukaemia or splenic lymphoma with villous lymphocytes. Neither plasmacytoid features nor cleaved nuclei were present. TRAP positivity was seen in the characteristic cells on peripheral blood and bone marrow smears and was evident in $10-58 \%$ of cells in cytospin preparations of peripheral blood from all patients (table 2). Characteristic TRAP positivity is shown in (fig 1B).

Trephine biopsy specimens from all four patients showed patchy diffuse infiltration by lymphoid cells which were larger than small lymphocytes and did not show cleaved nuclei or plasmacytoid features (fig 2).

\section{SPLENIC MORPHOLOGY AND HISTOLOGY}

The noticeably enlarged spleens (table 1) had a red-brown sectioned surface with diffuse prominence of Malpighian bodies in all patients. Histological examination showed expansion of the white pulp with only slight involvement of the red pulp (fig 3). The tumour cells were of uniform type (fig 4). They were medium to large, round, or oval lymphoid cells with a moderately high nuclear:cytoplasmic ratio, although non-basophilic cytoplasm was identifiable in all. Nuclear irregularity was slight and cleaved nuclei were not seen. The nuclei were open, and nucleoli, single or several, were prominent. Plasmacytoid cells were not a feature. Acid phosphatase staining was performed on splenic imprints (cases 1, 2, and 4) and showed characteristic $B$ cell pattern TRAP positivity in tumour cells (fig $5 \mathrm{~A}$ ).

Splenic hilar lymph nodes were obtained from two patients (cases 1 and 4). Both showed replacement of the normal architecture by a diffuse proliferation of cells of the same appearance described under splenic histology. Again, plasmacytoid cells were not a feature.

Electron microscopic studies showed the characteristic cell to have a large rounded nucleus and usually at least one prominent nucleolus. The cytoplasm was featureless apart from the presence of one or more mitochondria. Ribosomal lamellar complexes were not seen. Cells from the peripheral blood had occasional small surface projections, but cells in the spleen were closely packed and lacked any distinguishing surface features (fig 6).

\section{IMMUNOCYTOCHEMISTRY}

Three patients had a monoclonal population of B lymphoid cells in the peripheral blood $(\kappa$ light chain restriction in two and $\lambda$ in one, while the $\kappa: \lambda$ ratio of the fourth patient was suggestive of monoclonality (table 2 ). The abnormal cells on touch preparations of spleen or lymph node were positive with anti-CD19 and CD22 monoclonal antibodies and negative with antiCD2, 3, 4, and 8. They were also negative with anti-CD5 in the three patients (cases 1,2, and 4 ) in whom this antibody was tested (fig 5B). 
Figure 3 Section of spleen showing predominantly white pulp disease (case 1) (haematoxylin and eosin).

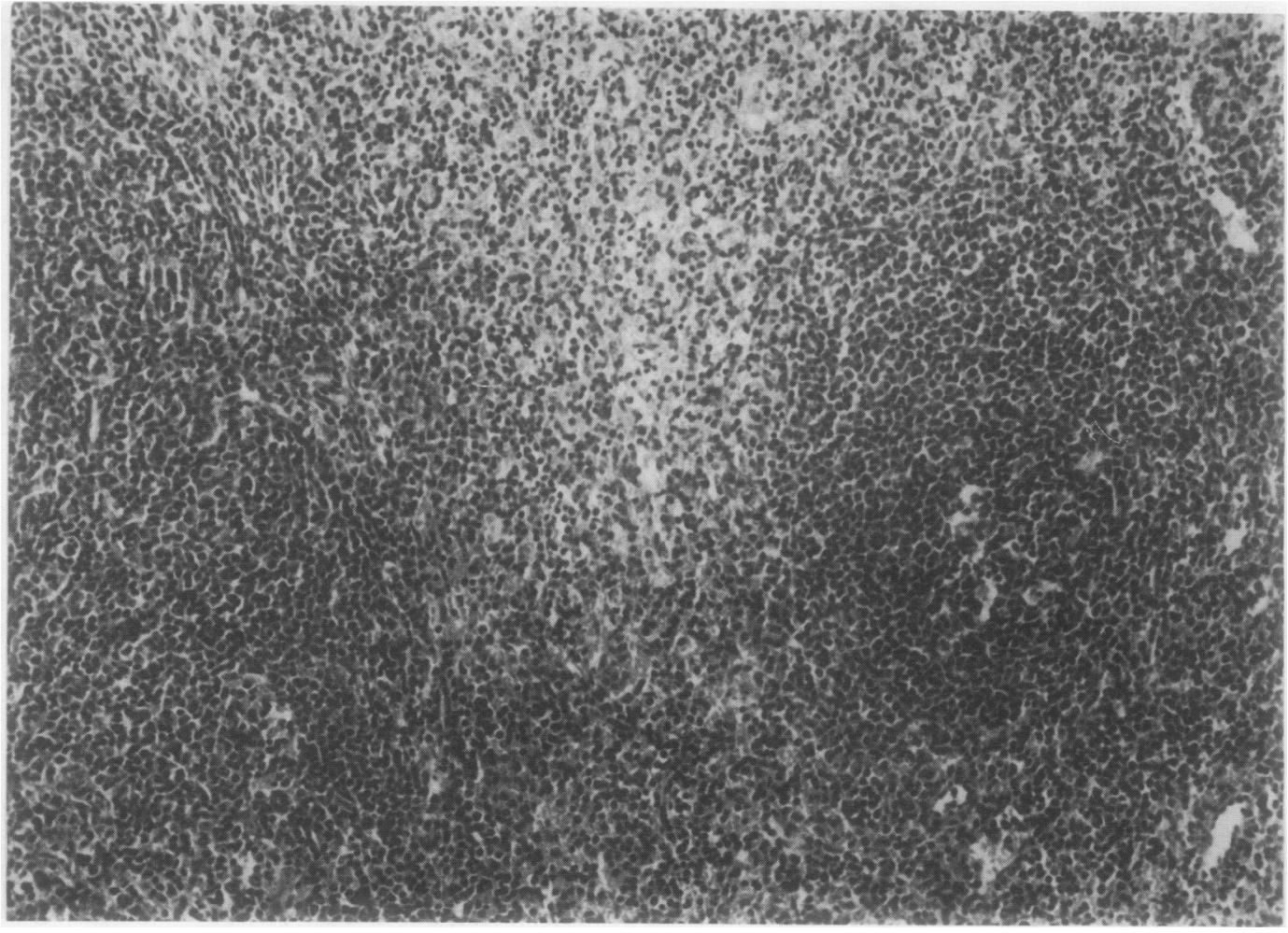

\section{Discussion}

Throughout 1989, the first year for which accurate figures are available, there were 146 cases of non-Hodgkin's lymphoma diagnosed in Northern Ireland (population 1.5 million). The area from which these patients came has an estimated population of 200000 , suggesting that about 19-20 cases of non-Hodgkin's lymphoma would have been expected during that period. Cases with isolated massive splenomegaly occur in less than $1 \%$ of lymphomas, however, ${ }^{3-6}$ so the finding of four such patients with identical lymphomata from an area of this size within a short space of time was unusual.

Although the patients described here share many of the features of several lymphoproliferative disorders, they seem to represent a distinct subset in that they cannot easily be fitted into any category in the classification of chronic "lymphoma/leukaemia" proposed by Bennett et al. ${ }^{7}$ They clearly do not have hairy cell leukaemia or hairy cell leukaemia variant (HCLV) because of the absence of hairy cells and the morphological appearances of spleen and bone marrow. BCLL, well differentiated
Figure 4 High power view of splenic infiltrate. Polymorphonuclear leucocyte (arrow) (case 1).

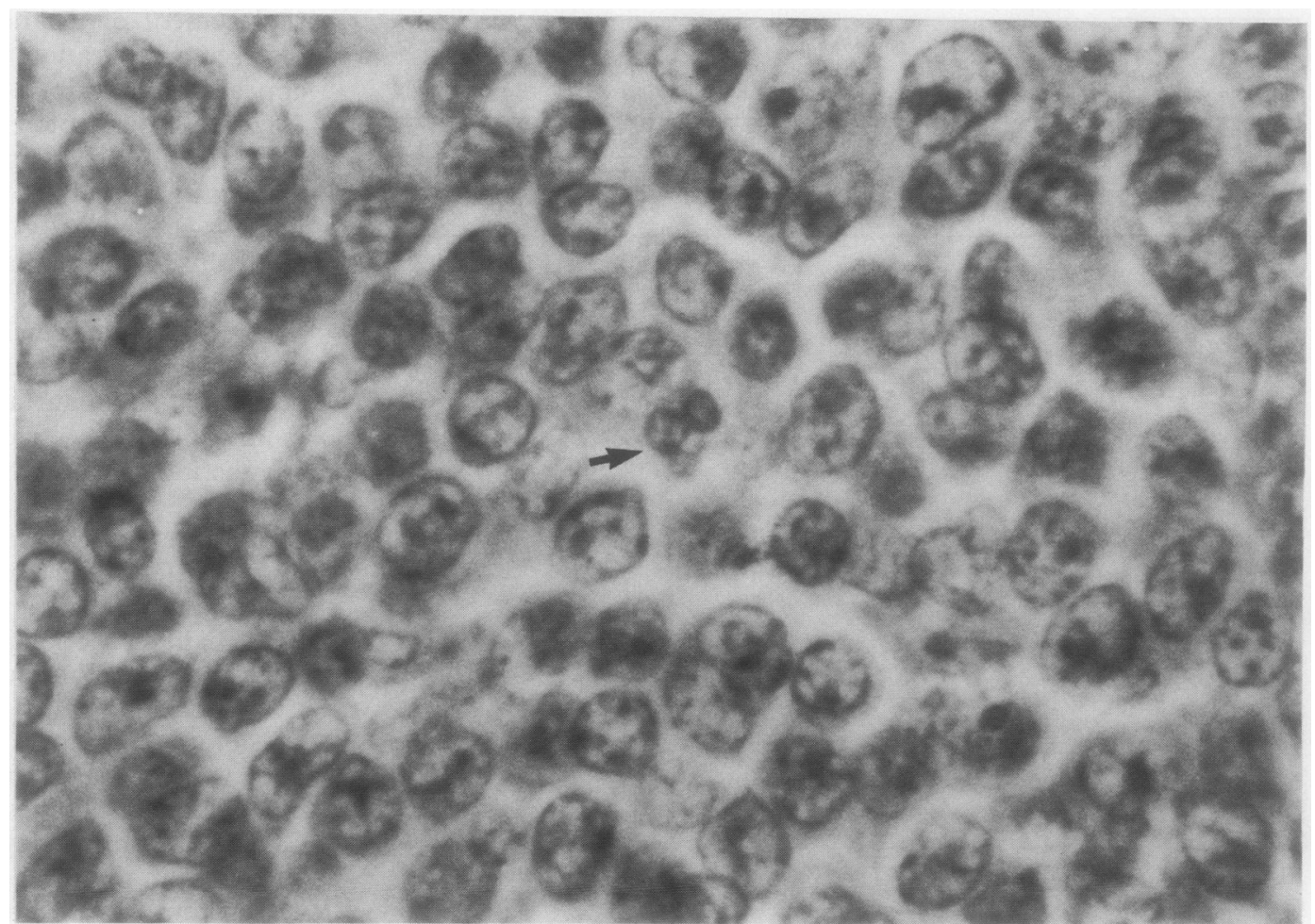


Figure 5 (A) TRAP positive cells on splenic imprint (case 4). (B) CDS positive small lymphocyte (arrow): lymphoma cells negative (lymph node imprint, case 1).
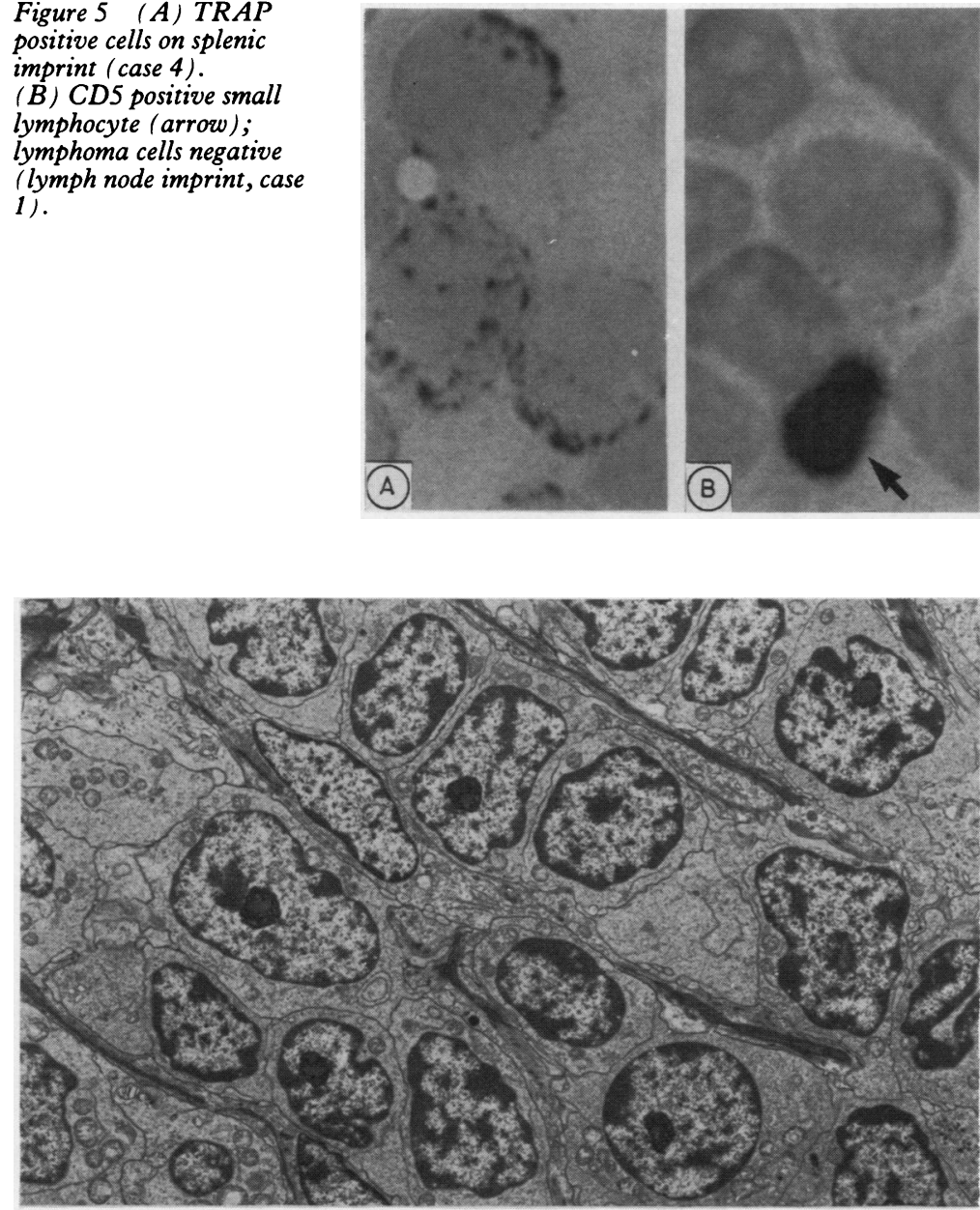

Figure 6 Electron micrograph of spleen (case 4).

lymphoma, and follicular lymphoma can be ruled out because in these conditions the cells are small, round lymphocytes or small, cleaved lymphocytes, respectively. A diagnosis of BPLL without major leukaemic spill is not possible. Splenic lymphoma with villous lymphocytes is again a disease of small lymphocytes which show villous projections and plasmacytoid features and positivity with anti-CD5 antibody. ${ }^{8}$ Spriano has described TRAP positivity in SLVL. ${ }^{9}$ Apart from TRAP positivity, these features do not correspond with those of our patients.
The condition which most resembles that of our patients is intermediate lymphocytic lymphoma (ILL). ${ }^{10}$ The features described in three series of patients with ILL are compared with those of our patients in table 3 . There is a similarity between our patients and those of Narang et al ${ }^{13}$ in that all presented with massive splenomegaly and showed a striking female predominance. Four of eight also showed TRAP positivity. The proliferating cells in our patients, however, were relatively uniform in type, could not be described as small lymphocytic, and nuclear irregularity was not a feature. On this basis, therefore, we believe that our patients can be distinguished from Narang's as well as those of the other two series. Notably, a pronounced male predominance was present in the other two series and this also suggests that different disease entities are involved. We consider, then, that our patients may form a distinct group, having identical clinical presentations and cellular proliferations, and not corresponding totally with any previously defined clinicomorphological entity. We have also seen a fifth patient (male) from the same area at the same time, who was clinically identical but his cellular proliferation (also TRAP positive) was that of centroblastic centrocytic lymphoma.

The TRAP positivity in our patients is of importance in that in any patient presenting with pronounced splenomegaly and absence of lymphadenopathy with circulating TRAP positive lymphoid cells the primary diagnoses to be considered are HCL and HCL variant. TRAP positivity has, however, been described as an occasional feature of many lymphomas. Whether this feature will help to classify our patients' splenic lymphoma as a distinct entity remains to be seen. Drexler has shown that it is possible to trigger the new expression of the TRAP isoenzyme in BCLL cells using the phorbol ester 12.0 , tetra deconal phorbol 13 acetate. ${ }^{14}$ The fact that all our patients presented with a rare type of lymphoma within a short space of time at a small district general hospital, which serves a largely rural and semirural area, may be coincidental. Perhaps it may suggest a common aetiological agent acting in a manner similar to this ester in causing TRAP

Table 3 Comparison of major features of intermediate lymphocytic lymphoma with those of our patients

\begin{tabular}{|c|c|c|c|c|}
\hline & Weisenburger et al" & De Oliveira et al ${ }^{\prime 2}$ & Narang et al ${ }^{l 3}$ & Belfast City Hospital series \\
\hline $\begin{array}{l}\text { No of patients } \\
\text { Median age } \\
\text { M:F ratio } \\
\text { Lymphadenopathy } \\
\text { Splenomegaly } \\
\text { Leukaemia }\end{array}$ & $\begin{array}{l}42 \\
65 \\
5: 1 \\
31 \\
16\end{array}$ & $\begin{array}{c}11 \\
65 \\
10: 1 \\
9 \\
7\end{array}$ & $\begin{array}{l}19 \\
62 \\
1: 5 \cdot 3 \\
2 \\
19\end{array}$ & $\begin{array}{c}4 \\
69 \\
0: 4 \\
0 \\
4\end{array}$ \\
\hline $\begin{array}{l}\left.\text { (lymphoid cells } 4 \times 10^{9} / 1\right) \\
\text { Characteristics of infiltrate } \\
\text { (histological) }\end{array}$ & $\begin{array}{l}9 \\
\text { Small lymphoid cells, } \\
\text { mixed round and } \\
\text { cleaved; chromatin } \\
\text { clumped to fine; } \\
\text { irregular nuclear } \\
\text { membrane; nucleoli not } \\
\text { mentioned in histological } \\
\text { description but were } \\
\text { noted in peripheral } \\
\text { blood cells in some cases }\end{array}$ & $\begin{array}{l}11 \\
\text { Atypical small and medium } \\
\text { sized lymphoid cells with } \\
\text { moderately condensed } \\
\text { nuclear chromatin, } \\
\text { inconspicuous small } \\
\text { nucleoli, and varying } \\
\text { degrees of nuclear } \\
\text { irregularity and cleaved } \\
\text { cells }\end{array}$ & $\begin{array}{l}5 \\
\text { Small lymphs with } \\
\text { irregular nuclear } \\
\text { borders; Occasional and } \\
\text { mixed small round and } \\
\text { cleaved cells; Non- } \\
\text { caseating granulomas }\end{array}$ & $\begin{array}{l}\text { 0 } \\
\text { Uniform cell type; larger than } \\
\text { polymorphonuclear } \\
\text { leucocyte; little nuclear } \\
\text { irregularity; nucleoli } \\
\text { prominent; no cleaved cells }\end{array}$ \\
\hline $\begin{array}{l}\text { TRAP } \\
\text { Anti-CD5 positivity }\end{array}$ & $\begin{array}{l}\text { ND } \\
\text { ND* }\end{array}$ & $\begin{array}{l}\text { ND } \\
11\end{array}$ & $\begin{array}{l}4 / 8 \\
\text { ND }\end{array}$ & $\begin{array}{l}4 \text { positive } \\
0 / 3\end{array}$ \\
\hline
\end{tabular}

^ND Not Done. 
positivity in these lymphomata, possibly contributing to their development.

We are grateful to Mrs M Ferris for expert secretarial assistance.

1 Shibata A, Bennett JM, Castoldi GL, et al. Recommended methods for cytological procedures in haematology. Clin Lab Haematol 1985;7:55-74.

2 Erber WN, Mynheer LC, Mason DY. APAAP labelling of blood and bone marrow samples for phenotyping leukaemia. Lancet 1986; i:761-5.

3 Skarin T, Davey FR, Moloney W.C. Lymphosarcoma of the spleen. Arch Intern Med 1971;127:259-65.

$4 \mathrm{Kim} \mathrm{H}$, Dorfman RF. Morphological studies of 84 untreated patients subjected to laparotomy for the staging of nonpatients subjected to laparotomy for the staging

5 Long JC, Aisenberg AC. Malignant lymphoma diagnosed at splenectomy and idiopathic splenomegaly. A clinicopathologic comparison. Cancer 1974;33:1054-61.

6 Strauss DJ, Filippa DA, Liebermann PH. The no Hodgkin's lymphomas I a retrospective clinical and pathological analysis of 499 cases diagnosed between 1958 and 1969. Cancer 1983;51:101-9.
7 Bennett JM, Catovsky D, Daniel MT, et al. Proposals for the classification of chronic (mature) $B$ and $T$ lymphoid leukaemias. J Clin Pathol 1989;42:567-84.

8 Melo JV, Hegde U, Parreira A, Thompson I, Lampert IA Catovsky D. Splenic B cell lymphoma with circulating villous lymphocytes: differential diagnosis of $B$ cell leukaemias with large spleens. J Clin Pathol 1987;40: 642-51.

9 Spriano P, Barosi G, Invernizzi R, et al. Splenomegalic immunocytoma with circulating hairy cells: report of eight cases and revision of the literature. Haematologica 1986; 71:25-33.

10 Braylan RC, Jaffe ES, Berard CW. Malignant lymphomas: current classification and new observations. Pathol Ann 1975;10:213-70.

11 Weisenburger DD, Nathwani BN, Diamond LW, Winberg CD, Rappaport MD. Malignant lymphoma, intermediate lymphocytic type. Cancer 1981;48:1415-25.

12 Pombo de Oliveira MS, Jaffe ES, Catovsky D. Leukaemic phase of mantle zone (intermediate) lymphoma: its characterisation in 11 cases. J Clin Pathol 1989;42:962-72.

13 Narang S, Wolf BC, Neiman RS. Malignant lymphoma presenting with prominent splenomegaly. Cancer 1985; presenting with prominent splenomegaly. Cancer 1985

14 Drexler HG, Klein M, Bhoopalam N, Gaedicke G, Minowada J. Morphological and isoenzymatic differentiation of $B$ chronic leukaemia cells induced by phorbol ester. Br J Cancer 1986;53:181-8. 